\title{
Effect of ovulation induction programs on the hormonal and lipid profile of mares maintained on pastures in the Brazilian Caatinga
}

\author{
Mychelle Bruna da Silva Barros, Monica Miranda Hunka, Luzilene Araujo de Souza, Helena Emília C. C. C. Manso and Helio Cordeiro \\ Manso Filho
}

Equine Research Nucleus, Department of Animal Science, Federal Rural University of Pernambuco, Recife, Pernambuco, Brazil

\begin{abstract}
Summary: Ovulation inducers are routinely used in domestic horses, especially when assisted reproduction technologies are applied, with the purpose of modulating hormonal activity. The objective of this study was to evaluate the variation of the sex hormones and the lipid profile of empty and single mares, subjected to the use of medicine regulators of the estrous cycle. We used 30 Mangalarga Marchador mares, aged between three and twelve years which were kept in the municipality of Limoeiro, Pernambuco, Brazil. In the presence of a follicle of $\geq 35 \mathrm{~mm}$ in diameter and endometrial oedema grade $\geq 2$, the mares were randomly separated into three experimental groups of ten animals each, which were treated with different ovulation inducers: i) G-HCG, 1,000 IU of human chorionic gonadotropin, intravenously; ii) G-Deslo, 1.0 mg deslorelin acetate, intramuscularly; iii) G-Combo, $1.0 \mathrm{mg} \mathrm{COMBO}{ }^{2}$, intramuscularly. All mares were artificially inseminated with chilled semen from one stallion. Blood samples were collected before the experiment and 2, 3, 9, and 15 days after ovulation by jugular venopuncture using vacuum system tubes without an anticoagulant. After centrifugation, serum was separated to measure the concentrations of luteinizing hormone (LH) and progesterone (P4) using an ELISA, and concentrations of triglycerides (TRIG), total cholesterol (COLE), high-density lipoproteins $(\mathrm{HDL})$, and low-density lipoproteins (LDL) were measured using semi-automated equipment. The use of oestrus cycle regulators produced significant variations in P4 and COLE whereas no significant effect was observed on LH, HDL, LDL, TRIG, and total plasma proteins (TPP). This likely resulted from endogenous mobilization required for metabolic adaptations at the onset of gestation, as the reproductive success rate of the three groups indicated that the treatments effectively induced and synchronized ovulation.
\end{abstract}

Keywords: cholesterol, horse, progesterone, reproductive efficiency, reproduction

Citation: Bruna da Silva Barros M., Hunka M. M., Araujo de Souza L., Manso H. E. C. C. C., Cordeiro Manso Filho H. (2019) Effect of ovulation induction programs on the hormonal and lipid profile of mares maintained on pastures in the Brazilian Caatinga. Pferdeheilkunde 35, 431-436; DOI 10.21836/PEM20190505

Correspondence: Dr. Mychelle Bruna da Silva Barros, Equina Research Nucleus, Department of Animal Science, Federal Rural University of Pernambuco, Av. Dom Manuel de Medeiros, 52171-030 Recife, Pernambuco, Brazil; mychellebarros@gmail.com

Received: December 26, 2018 | Accepted after revision: July 31, 2019

\section{Introduction}

Ovulation frequency in mares may vary throughout the year, which limits their reproductive efficiency in intensive breeding programs (Sousa et al. 2007, Kino et al. 2014). Therefore, the use of ovulation-inducing drugs has been encouraged to optimize breeding programs and thereby increase the reproductive efficiency of mares. Ovulation-inducing drugs that shorten the oestrous cycle and/or the inter-ovulatory interval can strongly affect the production of luteal progesterone (Perkins and Grimmet 2001, Nagao et al. 2012).

Human Chorionic Gonadotropin ( $\mathrm{hCG}$ ) has been used as an ovulation inducer in mares since the 1930s, with ovulations typically occurring between $36-42 \mathrm{~h}$ after treatment with 1,500 IU hCG (Ginther 1992). However, in the past decade, gonadotropin-releasing hormone $(\mathrm{GnRH})$ agonists, such as deslorelin acetate and buserelin, have been used as ovulation inducers. Deslorelin acetate induces ovulation in follicles of $\geq 35 \mathrm{~mm}$ in $79.3 \%$ of the mares between $24-48 \mathrm{~h}$ after ad- ministration (Melo et al. 2012), whereas buserelin requires three or four treatments every 6-12h (Barrier-Batut et al. 2001).

In addition to drug treatments to manipulate the oestrous cycle through endocrine modulation, it is known that nutritional management is important for reproducing mares as the diet provides nutrients for the formation of hormones (Losinno and Alvarenga 2006). Dietary adjustments can facilitate higher availability of lipids for hormone production and as a source of energy for the different reproductive phases. It is known that higher concentrations of lipids favour the production of cholesterol and therefore the mobilization of this metabolite for the steroid pathway, which in turn facilitates the production of steroid hormones by ovaries and placenta (Beato and Klug 2000).

We hypothesized that the production of sex hormones should be affected by both the concentration of lipids in the blood and by the use of drugs that regulate the oestrous cycle in 
mares. An experiment was conducted to assess the effect of different ovulation induction schemes on the variation of sex hormones and on the lipid profiles of empty and single mares. The identification of an efficient ovulation induction program which does not compromise the concentrations of lipid metabolism biomarkers may contribute to greater reproductive efficiency in horses in terms of increasing the number of produced foals.

\section{Material and Methods}

Selection of animals, assessments, and sonographic parameters

The experiment was carried out in the municipality Limoeiro-PE (07 $52^{\prime \prime}$ S, $\left.35^{\circ} 27^{\prime \prime} \mathrm{W}\right)$, Brazil. Thirty healthy Mangalarga Marchador mares between three and twelve years of age were used, with an average weight of $450 \mathrm{~kg}$ and with a body score between 4 and 6 (Henneke et al. 1983). The mares were kept in a semi-managed breeding regime on several hectares of pangola grass (Digitaria decumbens) pasture. Mineral salt (CoEqui Plus ${ }^{\circledR}$, Tortuga, Brazil) and water were available ad libitum, and no concentrate feed was provided. All mares were used regularly in breeding programs, and absence of uterine and ovarine alterations was confirmed through clinical and gynaecological examinations. Regularity of oestrus cycles was determined by rectal palpation and ultrasonography (A5V, SonoScape ${ }^{\circledR}$, China) by observing a complete oestrous cycle. The mares were monitored until ten days after giving birth in order to record the number of live foals at this point as an index of the stud's reproductive efficiency.

\section{Experimental groups and phases}

The experimental groups comprised 30 randomly chosen Mangalarga Marchador mares that had been monitored until the occurrence of natural ovulation. Seven days after this, the mares were injected intramuscularly with $5 \mathrm{mg} / \mathrm{mL}$ dinoprost tromethamine (Lutalyse ${ }^{\circledR}$, Zoetis, Brazil).

From twelve days after ovulation, the mares were examined by transrectal palpation and ultrasonography until a follicle of $\geq 35 \mathrm{~mm}$ was observed, as determined by the mean of the transverse measures of height and width, and occurrence of endometrial edema of degree $\geq 2$ (Samper 1997).

After this, ten mares were assigned to each one of the three experimental groups which received different ovulation inducers: G-hCG (1,000IU of human Chorionic Gonadotropin, intravenously), G-Deslo (1.0 mg deslorelin acetate, intramuscularly), and G-Combo (1.0 mg $\mathrm{COMBO}^{\circledR}$, intramuscularly); the treatments were followed by artificial insemination with chilled semen of the same stallion, $6 \mathrm{~h}$ after semen collection. The drug $\mathrm{COMBO}^{\circledR}$ is an association of deslorelin acetate (synthetic analog of $\mathrm{GnRH}$ ) with hCG, produced by Rancho das Américas, Brazil. Each mare was inseminated with a dose of 800 million viable spermatozoa. In each experimental phase, blood samples were collected via jugular venopuncture using a vacuum system and tubes without an anticoagulant. Serum was separated after centrifugation and was stored at $-18^{\circ} \mathrm{C}$ until processing.
Blood samples were collected 2, 3, 9, and 15 days after ovulation. Pre-experimental sampling was performed immediately before ovulation induction and before assignment to the respective treatment group. These samples were used to measure the concentrations of luteinizing hormone $(\mathrm{LH})$ and progesterone (P4) which were analysed using an ELISA and a semi-automatic reader (Bioclin Mindray MR-96A, Minas Gerais, Brazil), and the concentrations of triglycerides (TRIG), total cholesterol (COLE), HDL, and LDL were measured using commercial kits and semi-automatic equipment (Doles D-250, Goiás, Brazil). Statistical analyses

Differences between treatment groups and experimental phases were tested using a two-factor ANOVA and a Student-Newman-Keuls test. Correlations of hormones and lipid markers were tested using Pearson's correlation analysis. Statistical significance level of $5 \%$ was considered for all statistical assessments, and results have been shown as means \pm average standard error. SigmaPlot 13.0 software (Systat Software Ins., San Jose-CA, USA) was used for all analyses.

\section{Results}

The results showed that medical ovulation induction produced significant variations in P4 and COLE (Tables 1 and 2). No significant changes were observed in LH, LDL, HDL, TRIG, and TPP concentrations ( $>>0.05$; Tables 1 and 2). The P4 concentration increased earlier in the G-Combo treatment group, which was observed within the first $48 \mathrm{~h}$ and peaked after $72 \mathrm{~h}$. In the G-hCG and G-Deslo treatment groups the respective elevation was observed at $72 \mathrm{~h}$ and peaked on day 9 (Table 1). Regarding the lipid biomarkers, it was observed that the concentration of COLE initially changed significantly in the G-Deslo and G-Combo treatment groups, already at $48 \mathrm{~h}$, and in the G-hCG treatment group at $72 \mathrm{~h}$, and the G-Deslo treatment produced the highest concentration $(\sim 157 \mathrm{mg} / \mathrm{dL})$ at this stage (Table 2). The lowest COLE concentration was found in the G-Combo treatment on day 15.

The results of Pearson's correlation analyses of each treatment showed a non-significant correlation trend of $\mathrm{P} 4$ and $\mathrm{LH}$ in the G-hCG treatment $(R=0.39 ; p=0.07)$. In the $G$-Deslo treatment, correlations of $\mathrm{P} 4$ and $\mathrm{HDL}(\mathrm{R}=0.36 ; \mathrm{p}=0.03)$ and of P4 and LDL $(R=-0.34 ; p=0.05)$ were observed, whereas in the G-Combo treatment, correlations of P4 and TRIG (R = $-0.624 ; p<0.001)$ and of $P 4$ and $\operatorname{LL}(R=-0.424 ; p=0.02)$ were found; furthermore, and a non-significant correlation trend of $\mathrm{P} 4$ and $\mathrm{HDL}$ was observed $(R=0.33 ; p=0.07)$. A correlation between COLE and LDL $(R=0.32 ; p=0.03)$ was also observed in the G-Combo treatment (Table 3).

Analysing the inseminated mares, it was observed that all ovulated independently of the protocol used and pregnancy was confirmed by ultrasonography on day 15 post-ovulation. In the G-hCG and G-Combo treatment, only six of the respective inseminated mares were pregnant (60\%), whereas seven mares of the G-Deslo treatment group were pregnant (70\%; Table 4). The proportion of pregnant mares remained stable and corresponded to the number of live foals ten days after birth. None of the treatments produced any adverse reactions. 
Table 1 Concentrations of luteinizing hormone (LH) and progesterone (P4) in the plasma of Mangalarga Marchador mares subjected to three distinct medication programs for ovulation induction. | Konzentrationen von luteinisierendem Hormon (LH) und Progesteron (P4) im Plasma von Mangalarga Marchador Stuten, die drei verschiedenen Medikamentenprogrammen zur Ovulationsinduktion unterzogen wurden.

\begin{tabular}{|c|c|c|c|c|c|}
\hline \multirow[t]{2}{*}{ Group } & \multicolumn{5}{|c|}{ Experimental phase } \\
\hline & Pretest & 2nd day & 3rd day & 9th day & 15th day \\
\hline \multicolumn{6}{|l|}{$\mathrm{LH}, \mathrm{ng} / \mathrm{dL}$} \\
\hline Control $(n=30)$ & $3.28 \pm 1.38$ & - & - & - & - \\
\hline G-hCG $(n=10)$ & - & $4.66 \pm 3.19$ & $1.41 \pm 0.50$ & $9.12 \pm 5.11$ & $10.99 \pm 6.79$ \\
\hline G-Deslo $(n=10)$ & - & $4.14 \pm 2.78$ & $4.75 \pm 3.06$ & $4.21 \pm 2.27$ & $4.41 \pm 2.68$ \\
\hline G-Combo $(n=10)$ & - & $0.73 \pm 0.20$ & $0.74 \pm 0.36$ & $2.05 \pm 0.14$ & $0.31 \pm 0.01$ \\
\hline \multicolumn{6}{|l|}{ Progesterone } \\
\hline Control $(n=30)$ & $8.68 \pm 2.57 \mathrm{~B}$ & - & - & - & - \\
\hline G-hCG $(n=10)$ & - & $4.19 \pm 1.62 B$ & $18.01 \pm 6.29 A B$ & $32.65 \pm 5.39 A$ & $22.29 \pm 7.24 A B$ \\
\hline G-Deslo $(n=10)$ & - & $3.31 \pm 1.29 B$ & $27.90 \pm 9.11 \mathrm{AB}$ & $32.42 \pm 7.07 \mathrm{~A}$ & $9.37 \pm 1.30 \mathrm{AB}$ \\
\hline G-Combo $(n=10)$ & - & $11.49 \pm 5.65 \mathrm{AB}$ & $35.29 \pm 6.65 \mathrm{~A}$ & $19.88 \pm 2.75 \mathrm{AB}$ & $30.55 \pm 10.76 \mathrm{AB}$ \\
\hline
\end{tabular}

Note: Different letters, independent of the row or column, indicate that $p<0.05$ by Student-Newman-keuls test for the same biomarker.

Table 2 Concentrations of COLE, HDL, LDL, TRIG and TPP of Mangalarga Marchador mares submitted to three distinct ovulation induction drug programs. I Konzentrationen von COLE, HDL, LDL, TRIG und TPP von Mangalarga Marchador Stuten, die bei drei verschiedenen Ovulationsinduktionsprogrammen eingereicht wurden.

\begin{tabular}{|c|c|c|c|c|c|}
\hline \multirow[t]{2}{*}{ Group } & \multicolumn{5}{|c|}{ Experimental phase } \\
\hline & Pretest & 2nd day & 3rd day & 9th day & 15th day \\
\hline \multicolumn{6}{|l|}{ Total Cholesterol, mg/dL } \\
\hline Control $(n=30)$ & $118.53 \pm 5.67 \mathrm{AB}$ & - & - & - & - \\
\hline G-hCG $(n=10)$ & - & $125.82 \pm 7.45 \mathrm{AB}$ & $141.17 \pm 12.5 \mathrm{AB}$ & $124.19 \pm 7.88 \mathrm{AB}$ & $133.57 \pm 6.4 \mathrm{AB}$ \\
\hline G-Deslo $(n=10)$ & - & $156.92 \pm 26.33 \mathrm{~A}$ & $126.35 \pm 14.9 \mathrm{AB}$ & $137.06 \pm 10.7 A B$ & $141.31 \pm 8.9 A B$ \\
\hline G-Combo $(n=10)$ & - & $113.02 \pm 5.50 \mathrm{AB}$ & $106.47 \pm 5.03 \mathrm{AB}$ & $106.84 \pm 4.40 \mathrm{AB}$ & $100.97 \pm 4.3 B$ \\
\hline \multicolumn{6}{|l|}{$\mathrm{LDL}, \mathrm{mg} / \mathrm{dL}$} \\
\hline Control $(n=30)$ & $88.23 \pm 6.93$ & - & - & - & - \\
\hline G-hCG $(n=10)$ & - & $93.16 \pm 8.19$ & $112.74 \pm 10.32$ & $84.12 \pm 9.41$ & $93.25 \pm 6.82$ \\
\hline G-Deslo $(n=10)$ & - & $88.96 \pm 19.73$ & $81.13 \pm 19.24$ & $86.72 \pm 17.97$ & $110.66 \pm 13.78$ \\
\hline G-Combo $(n=10)$ & - & $71.13 \pm 11.91$ & $63.52 \pm 10.14$ & $79.27 \pm 8.32$ & $70.70 \pm 9.88$ \\
\hline \multicolumn{6}{|l|}{$\mathrm{HDL}, \mathrm{mg} / \mathrm{dL}$} \\
\hline Controle $(n=30)$ & $64.02 \pm 31.56$ & - & - & - & - \\
\hline G-hCG $(n=10)$ & - & $32.66 \pm 6.24$ & $28.43 \pm 4.32$ & $40.07 \pm 8.66$ & $40.32 \pm 8.02$ \\
\hline G-Deslo $(n=10)$ & - & $57.57 \pm 20.16$ & $65.52 \pm 16.91$ & $50.34 \pm 11.56$ & $43.69 \pm 12.37$ \\
\hline G-Combo $(n=10)$ & - & $41.89 \pm 11.25$ & $42.95 \pm 10.16$ & $49.81 \pm 12.87$ & $53.77 \pm 13.85$ \\
\hline \multicolumn{6}{|l|}{ Triglycerides, mg/dL } \\
\hline Control $(n=30)$ & $37.84 \pm 3.26$ & - & - & - & - \\
\hline G-hCG $(n=10)$ & - & $42.86 \pm 4.11$ & $27.31 \pm 6.91$ & $42.99 \pm 3.92$ & $44.13 \pm 5.43$ \\
\hline G-Deslo $(n=10)$ & - & $37.04 \pm 4.69$ & $37.37 \pm 5.71$ & $46.99 \pm 9.19$ & $47.90 \pm 8.72$ \\
\hline G-Combo $(n=10)$ & - & $35.33 \pm 2.41$ & $34.14 \pm 4.78$ & $34.23 \pm 3.04$ & $33.96 \pm 3.78$ \\
\hline \multicolumn{6}{|l|}{ TPP, mg/dL } \\
\hline Control $(n=30)$ & $7.10 \pm 0.09$ & - & - & - & - \\
\hline G-hCG $(n=10)$ & - & $7.22 \pm 0.15$ & $7.38 \pm 0.34$ & $6.94 \pm 0.17$ & $7.50 \pm 0.38$ \\
\hline G-Deslo $(n=10)$ & - & $7.20 \pm 0.08$ & $7.34 \pm 0.21$ & $7.58 \pm 0.18$ & $7.16 \pm 0.21$ \\
\hline G-Combo $(n=10)$ & - & $6.68 \pm 0.16$ & $7.00 \pm 0.10$ & $7.56 \pm 0.42$ & $7.20 \pm 0.18$ \\
\hline
\end{tabular}

Note: Different letters, independent of the row or column, indicate that $p<0.05$ by Student-Newman-keuls test for the same biomarker. 


\section{Discussion}

The three tested protocols of ovulation induction produced similar results and showed some degree of variation in the concentrations of hormonal and lipid biomarkers (Davies-Morel and Newcombe 2008, Greco 2016), indicating the metabolic relationship among these factors in animals in intense breeding programs, even without noticeable changes in body scores. As expected, no variations in $\mathrm{LH}$ were observed after ovulation induction, in contrast to the observed pattern of P4. In the G-Combo group, P4 increased already on day 3, whereas in G-hCG and G-Deslo this elevation was observed on day 15, indicating that this treatment may stimulate greater usage of compounds needed for hormone production in different periods. The statistical analysis was done to compare both the drugs and the experimental phase to allow understanding of the action of drugs in the studied periods, and in this way, define the practical applicability of the drugs.

The highest availability of COLE occurred on day 2 in the G-Deslo treatment and was significantly reduced in the G-Combo treatment on day 15. Interestingly, COLE concentrations were not affected by the treatments, whereas $L D L$ and HDL were affected by the G-Deslo and G-Combo treatments. In the G-Combo treatment, we found a strong negative correlation with triglycerides, which after degradation produce glycerol and free fatty acids. These compounds are important molecules for energy production for different metabolic processes such as the production of hormones including P4 for maintaining gestation.

LH is important for normal development and luteal function, and it is responsible for stimulating luteal cells to secrete pro- gesterone (Niswender et al. 2003). In mares, an LH peak occurs approximately two days after ovulation, and circulating LH remains elevated for about a week or more after ovulation (Miller et al. 1981). Ginther (1992) and Greco (2016) observed lower LH levels five days after ovulation due to a negative feedback of luteal P4; a different pattern was observed in the present study, although not statistically significant (Table 1).

P4 is a hormone secreted by lutein cells in the form of granules and also by the placenta and adrenals. Plasma progesterone concentration is closely linked with alterations in the corpus luteum (van Niekerk et al. 1975), and progesterone secretion is essential for establishment of gestation and maintenance of pregnancy (Holtan et al. 1979). P4 increases in the majority of mares between 10-12 $\mathrm{h}$ post-ovulation; however, because of considerable inter-individual variation, this increase may occur between 6-60 h post-ovulation (Townson et al. 1989), as observed in the G-Combo treatment group (Table 1). Ginther (2006) found an increase in the level of serum P4 shortly after ovulation, reaching a maximum of about $10 \mathrm{ng} / \mathrm{mL}$ on day 6, which is then maintained until day 13-14 post-ovulation if luteolysis does not occur.

In a study conducted by Kanitz et al. (2007), mares treated with GnRH showed a continuous increase in the mean of $\mathrm{P} 4$ from day 0 to day 8 day post-ovulation, both in treated individuals and controls, and between day 9 and day 11 which was not statistically significant. These findings corroborate the results of the current study, where in the G-hCG and G-Deslo treatments, a continuous increase in P4 occurred after $72 \mathrm{~h}$, which peaked on day 9 (Table 1). This was in line with the results of Ginther et al. (2007a), where P4 increased significantly in the luteal phase of 20 cyclical mares on day

Table 3 Correlation between post-ovulation progesterone concentration and different hormonal and biochemical biomarkers in inseminated mares after ovulation induction according to treatment. | Zusammenhang zwischen der Progesteronkonzentration nach dem Eisprung und verschiedenen hormonellen und biochemischen Biomarkern bei besamten Stuten nach der Ovulationsinduktion gemäß der Behandlung.

\begin{tabular}{l|cccccc}
\hline Progesterone & \multicolumn{7}{|c}{ Biomarker } \\
\hline & LH & Triglycerides & Cholesterol Total & HDL & LDL & TPP \\
\hline G-hCG & $0.39 ; p=0.07$ & NS & NS & NS & NS & NS \\
G-Deslo & NS & NS & NS & $0.36 ; p=0.03$ & $-0.34 ; p=0.05$ & NS \\
G-Combo & NS & $-0.62 ; P<0.001$ & NS & $0.33 ; p=0.07$ & $-0.42 ; p=0.02$ & NS \\
\hline
\end{tabular}

Table 4 Uterine and ovulatory characteristics in the pre-test and parameters of reproductive efficiency of Mangalarga Marchador mares subjected to three distinct medication programs for ovulation induction. | Harnröhren- und Ovulationsmerkmale im Vorversuch und Parameter der Fortpflanzungsleistung von Mangalarga Marchador Stuten, die drei verschiedenen Medikamentenprogrammen zur Ovulationsinduktion unterzogen wurden.

\begin{tabular}{|c|c|c|c|c|c|c|}
\hline \multirow[t]{2}{*}{ Treatment } & \multicolumn{2}{|c|}{$\begin{array}{c}\text { Uterine and ovulatory characteristics in } \\
\text { the pre-test }\end{array}$} & \multicolumn{4}{|c|}{ Evaluation of reproductive efficiency } \\
\hline & Uterine Edema & $\begin{array}{l}\text { Follicular diameter } \\
\qquad(\mathrm{mm})\end{array}$ & $\begin{array}{c}\text { Number of } \\
\text { inseminated } \\
\text { Mares }\end{array}$ & $\begin{array}{l}\text { Number of } \\
\text { mares pregnant } \\
\text { at } 15 \text { days }\end{array}$ & Number of mares & $\begin{array}{l}\text { Live foals } \\
\text { after } 10 \text { days }\end{array}$ \\
\hline G-hCG & 3 & 38.3 & 10 & 6 & 6 & 6 \\
\hline G-Deslo & 3 & 38.6 & 10 & 7 & 7 & 7 \\
\hline G-Combo & 3 & 38 & 10 & 6 & 6 & 6 \\
\hline
\end{tabular}

Notes: Endometrial edema according to the scale cited by Samper (1997); Follicular diameter obtained by the transverse mean of height and width in mm. 
8 post-ovulation, and decreased between days 15 and 17 post-ovulation, which corresponded to the luteolytic period.

According to Ginther (1992), an early increase in P4 concentrations as observed in the G-Combo treatment (Table 1) leads to the increased uterine secretion of substances which are essential for nutrient supply during the early stage of embryonic development. Moreover, there is a relationship between the onset of gestation and the endometrial secretion of several proteins associated with hormonal changes during the oestrous cycle (Brück et al. 1993). A limiting step in the biosynthesis of P4 is the transport of cholesterol to the internal mitochondrial membrane (Crivello and Jefcoate 1980, Jefcoate et al. 1987), which also seems to be the primary pathway of acute hormonal regulation (Grusenmeyer and Pate 1992, Wiltbank et al. 1993, Belfiore et al. 1994). Cholesterol is thus transported to the external and to the internal mitochondrial membrane, where it is cleaved to produce pregnenolone (Niswender 2002, Papadopoulus et al. 1997), a precursor of P4.

It was done a comparison since drug induction until pregnancy diagnosis, at 15 days after Artificial Insemination, for understanding the complex relationship between reproduction and essential fatty acids that occurs through mechanisms that involve the synthesis of prostaglandin F2 $\alpha$ (PGF2 $\alpha$ ) (Petit et al. 2002), and the increase of this factor is correlated with elevations in cholesterol concentrations. It can reach the luteal cell in the three distinct forms of LDL, HDL, and cholesterol ester. Under normal conditions, the vast majority of cholesterol used for steroid synthesis is derived from the circulatory system in the form of LDL and HDL (Niswender 2002).

In the present study, the onset of the G-hCG P4 increase and the highest COLE concentration occurred after $72 \mathrm{~h}$. The G-Deslo treatment produced the highest COLE concentration and the lowest P4 level after $48 \mathrm{~h}$. In the G-Combo treatment, higher COLE concentrations and a P4 peak were observed within the first $48 \mathrm{~h}$, which is in line with the fact that higher cholesterol concentrations lead to higher bioavailability of progesterone due to its participation in the formation of pregnenolone (Table 1 and 2).

The reproductive efficiency of the three treatment groups indicated that the tested treatments effectively induced and synchronized ovulation, as reported in previous studies (Squires et al. 2007, Ferris et al. 2011 ). Follicles were $\geq 35 \mathrm{~mm}$ in diameter, as determined by transrectal ultrasonography, which is generally considered the size of dominant follicles and is one of the main criteria to determine the proximity of ovulation in mares (Cuervo-Arango and Newcombe 2008). The classification of endometrial oedema in the pre-ovulatory stage was in line with the scoring system proposed by Samper (1997); the evaluation of endometrial oedema is an auxiliary tool to determine the optimal moment for insemination of a mare (Cuervo-Arango and Newcombe 2008).

The body score of the mares did not change in the initial period of 15 days, and subsequent observed alterations were due to endogenous mobilization as the dietary scheme was not modified.

\section{Conclusion}

The post-ovulation phase and early pregnancy are characterized by intense metabolic adaptations, with increased secretion of P4 and increased use of blood lipids. Therefore, mares used in breeding programs should have sufficient body fat reserves to facilitate hormone production for the maintenance of pregnancy until the formation of the placenta.

\section{Conflict of interest}

None of the authors have any conflict of interests.

\section{Animal Welfare Statement}

The UFRPE-CEUA Ethics and Animal Welfare commission authorized this research by protocol No. 56/2017.

\section{References}

Barrier-Battut I., Le Poutre N., Trocherie E., Hecth S., Grandehamp Des Raux D., Nicaise J. L., Vérin X., Bertrand J., Fiéni F., Hoier R., Renault A., Engron L., Tainturier D., Bruyas J. F. (2001) Use of buserelin to induce ovulation in cyclic mares. Theriogenology 55, 1679-1695.

Beato M., Klug J. (2000) Steroid hormone receptors: an update. Human Reproduction Update 6, 225-236

Belfiore C. J, Hawkins D. E., Wiltbank M. C., Niswender G. D. (1994) Regulation of cytochrome P 450scc synthesis and activity in the ovine corpus luteum. J. Steroid Biochem. Molec. Biol. 51, 283-290

Brück I., Anderson G., Hyland J. H. (1993) Reproductive performance of thoroughbred mares on six commercial syud farms. Austr. Vet. J. 70, 299-303

Cuervo-Arango J., Newcombe J. R. (2008) Repeatability of preovulatory follicular diameter 26 and uterine edema pattern in two consecutive cycles in the mare and how they are 27 influenced by ovulation inductors. Theriogenology 69, 681-687

Crivello J. F., Jefcoate C. R. (1980) Intracellular movement of cholesterol in rat adrenal cells. Kinetics and effects of inhibitors. Biol. Chem. 255, 8144-8151

Davies Morel M. C. G., Newcombe J. R. (2008) The efficacy of different hCG dose rates and 16 the effect of hCG treatment on ovarian activity: ovulation, multiple ovulation, 17 pregnancy, multiple pregnancy, synchrony of multiple ovulation; in the mare. Ani. Reprod. Sci.109, 189-199

Ferris R. A., Hatzel J. N., Lindholm R. G., Scofield D. B., Mccue P. M. (2011) Efficacy of deslorelin acetate (sucromate) on induction of ovulation in american quarter horse mares. J. Equine Vet. Sci. 32, 1-4

Ginther O. J. (1992) Reproductive Biology of the Mare: Basic and Applied aspects. 2th ed. Wisconsin: Equiservices, Cross Plains.

Ginther O. J., Utt M. D., Bergfelt D. R., Beg M. A. (2006) Controlling interrelationships between progesterone/LH and estradiol/LH during the equine estrous cycle. Anim. Reprod. Sci. 95, 144-150

Ginther O. J., Utt M. D., Beg M. A., Gastal E. L., Gastal M. O. (2007a) Negative effect of estradiol on luteinizing hormone throughout the ovulatory luteinizing hormone surge in mares. Biol. Reprod. 77, 543-550

Greco G. M. (2016) Eficiencia de diferentes agentes indutores da ovulação e associações sobre as características uterinas, ovarianas e concentrações plasmáticas de LH em éguas. Botucatu (SP): Universidade Estadual Paulista 
Grusenmeyer D .P., Pate J. L. (1992) Localization of prostaglandins F2 $\alpha$ inhibition of lipoprotein use by bovine luteal cells Journal of Reproduction and Fertility 94, 311-318

Henneke D. R., Potter G. D., Kreider J. L., Yeates B. F. (1983) Relationship between condition score, physical measurement, and body fat percentage in mares. Equine Vet. J. 15, 371-372

Holtan D. W., Squires E. L., Lapin D. R., Ginther O. J. (1979) Effect of ovariectomy on pregnancy in mares. Reprod. Fertil. (Suppl.) 27, 457-463

Jefcoate C. R., Dibartolomeis M. J., Williams C. A., Mcnamara B. C. (1987) ACTH regulation of cholesterol movement in isolated adrenal cells. J. Steroid Biochem. 27, 721-729

Kanitz W., Schneider F., Hoppen H. O., Unger C., Numberg G., Becker F. (2007) Pregnancy rates, LH and progesterone concentrations in mares treated with a GnRH agonist. Anim. Reprod. Sci. 97, 55-62

Kino S., Osawa T., Mizuno S., Watanabe G., Taya K., Izaike Y. (2014) Effect of postbreeding intramuscular administration of deslorelin acetate on plasma LH and progesterone concentrations and conception rate in mares. J. Equine Vet. Sci. 25, 23-27

Losinno L., Alvarenga M. A. (2006) Fatores críticos em programas de Transferência de Embriões no Brasil e Argentina. In: Reunião Anual da Sociedade Brasileira de tecnologia de embriões. Araxá. Acta Scient. Vet. 34, 39-49

Melo C. M., Papa F. O., Puoli Filho J. N. P., Araújo G. H., Dell'aqua Jr J. A., Alvarenga. M. A. (2012) Eficiência do acetato de deslorelina e do extrato de pituitária eqüina na indução da ovulação em éguas. Veterinária Zootec. 19, 392-398

Miller P. A., Wesson J. A., Ginther O. J. (1981) Interaction of estradiol and a nonsteroidal follicular fluid substance in the regulation of gonadotropin secretion in the mare. Biol. Reprod. 24, 354-358

Nagao J. F., Neves Neto J. R., Papa F. O., Alvarenga M. A., Freitas-Dell'aqua C. P., Dell'aqua J. A. (2012) Induction of double ovulation in mares using deslorelin acetate. Anim. Reprod. Sci. 136, 69-73
Niswender G. D. (2002) Molecular control of luteal secretion of progesterone. Reproduction 123, 333-339

Niswender G. D., Alvarenga M. A., Mccue P. M., Hardy Q. P., Squires E. L. (2003) Superovulation in cycling mares using equine follicle stimulating hormone (eFSH). J. Equine Vet. Sci. 23, 497-500

Papadopoulos V., Amri H., Boujrad N. et al. (1997) Peripheral benzodiazepine receptor in cholesterol transport and steroidogenesis. Steroids 62, 21-28

Perkins N. R., Grimmett J. B. (2001) Pregnancy and twinning rates in Thoroughbred mares following administration of human chorionic gonadotrophin (hCG). New Zealand Vet. J. 49, 94-100

Petit H. V., Dewhurst R. J., Scollan N. D. et al. (2002) Milk production and composition, ovarian function, and prostaglandin secretion of dairy cows fed omega-3 fats. Dairy Sci. 85, 889-899

Samper J. C. (1997) Ultrasonographic appearance and the pattern of uterine edema to time ovulation in mares. Proceedings of the American Association of the Equine Practioners 43,189-191

Sousa F. A. C., Fleury P. D. C., Alonso M. A., Andrade A. F. C., Arruda R. P. (2007) Aumento da disponibilidade de éguas receptoras de embrião após tratamento com gonadotrofina coriônica humana (hCG). Acta Sci. Vet. 35 (Suppl.), 1258

Squires E. L., Mccue P. M. (2007) Superovulation in mares. Anim. Reprod. Science. 9, 1-8

Twonson D. H., Pierson R. A., Ginther O. J. (1989) Characterization of plasma progesterone concentrations for two distinct luteal morphologies in mares. Theriogenology 32, 197-204

van Niekerk C. H., Morgentthal J. C., Gerneke H. W. (1975) Relationship between the morphology of and progesterone production by the corpus luteum of the mare, J. Reprod. Fertil. Suppl. 23, $171-175$

Wiltbank M. C., Belfiore C. J., Niswender G. D. (1993) Steroidogenic enzyme activity after acute activation of protein kinase (PK) A and PKC in ovine small and large luteal cells. Molec. Cell. Endocrinol. $97,1-7$ 